\title{
A Case of Bilateral Peripheral Tapia's Syndrome Subsequent to Coronary Artery Bypass Graft
}

\author{
Seung Woo Kim ${ }^{1}$, Min Suk Kim ${ }^{2}$, Jeon $\mathrm{Ha} \mathrm{Choi}^{1}$ and Choon Dong Kim ${ }^{1}$ \\ ${ }^{1}$ Department of Otolaryngology-Head and Neck Surgery, VHS Medical Center, Seoul; and \\ ${ }^{2}$ Department of Anesthesilogy and Pain Medicine, Seoul Wooridul Hospital, Seoul, Korea
}

\author{
관상동맥 우회술 이후에 발생한 양측성 타피아 증후군 1 예 \\ 김승우 ${ }^{1} \cdot$ 김민석 $^{2} \cdot$ 최전하 $^{1} \cdot$ 김춘동 $^{1}$ \\ 중앙보훈병원 이비인후과, ${ }^{1}$ 서울 우리들병원 마취통증의학과 ${ }^{2}$
}

\author{
Received May 28, 2013 \\ Revised July 5, 2013 \\ Accepted July 8, 2013 \\ Address for correspondence \\ Seung Woo Kim, MD \\ Department of Otolaryngology- \\ Head and Neck Surgery, \\ VHS Medical Center, \\ 53 Jinhwangdo-ro 61-gil, \\ Gangdong-gu, Seoul 134-791, Korea \\ Tel +82-2-2225-1384 \\ Fax $+82-2-2225-1385$ \\ E-mail entzzang1020@daum.net
}

The Tapia's syndrome means symptom complex that result from unilateral vago-hypoglossal nerve paralysis. This syndrome is rare disease entity, bilateral attack is extremely rare. Only three cases have been reported in English literature. A-66-year-old man received the coronary artery bypass graft in our hospital. After the operation, he complained of severe dyspnea, voice change and drooling. The laryngoscopic findings showed the bilateral vocal cord palsy. He could not move the tongue toward any directions. We diagnosed as bilateral Tapia's syndrome. Usually, unilateral Tapia's syndrome is related to the complications of anesthesia and position of the patient's head during surgery. Otherwise, our case may be associated with the complications of operation and anesthesia. The patient's recovered three months later, but the right vocal cord palsy is persistent. We report the very unique disease entity with literature review.

Korean J Otorhinolaryngol-Head Neck Surg 2013;56:535-7

Key Words Bilateral · CABG · Orotracheal intubation · Tapia's syndrome.

\section{Introduction}

Tapia's syndrome was originally described in 1904 by the Spanish otorhinolaryngologist A. G. Tapia." It means the symptom complex that come from vago-hypoglossal nerve paralysis. ${ }^{1)}$ This disease is relatively rare, had been reported about dozens of cases so far. ${ }^{2)}$ Most of the reported cases are unilateral, and only three cases are bilateral involvements. ${ }^{3-5)}$ This syndrome can be classified into two types; central and peripheral. The former is intramedullary lesions of the nucleus ambiguus, nucleus of the hypoglossal nerve, and pyramidal tract. The latter is an extracranial involvement of the recurrent laryngeal nerve (RLN) and hypoglossal nerve (HN). ${ }^{1,5)}$ Most of the mechanisms of injury are known to be neuropraxia. ${ }^{5)}$ We report a unique case of bilateral Tapia's syndrome with literature review.

\section{Case}

A 63-year-old man underwent coronary artery bypass graft $(\mathrm{CABG})$ in department of cardiac surgery. Routine endotracheal intubation and extubation were done, but the intubation was slightly difficult due to the patient's short neck. The intubation tube size was inner diameter of $8.0 \mathrm{~mm}$ and an outer diameter of $11.5 \mathrm{~mm}$, and the cuff pressure was under $20 \mathrm{cmH}_{2} \mathrm{O}$. The operation time was $340 \mathrm{~min}$. The method of CABG was on-pump beating [right internal thoracic artery (ITA)-left anterior descending, left ITA-obtuse marginal]. After the surgery, the patient was delivered to the coronary care unit (CCU) and extubation was performed eighteen hours later. After 4 days in $\mathrm{CCU}$, he was move to general ward without any specific problems. After moving into the general ward, he complained of severe dyspnea, dysphonia and drool- 

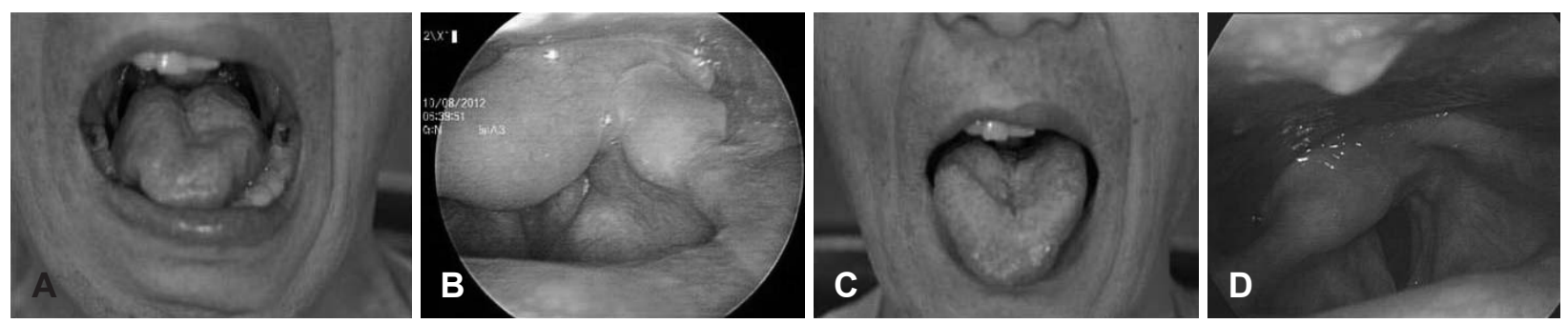

Fig. 1. This photo shows that the tongue is inability to move (A). The laryngoscopic finding shows midline position of the bilateral vocal folds (B). This photo shows the full recovery of tongue motion (C). The laryngoscopic finding shows paramedian fixation of right true vocal cord (TVC) and full abduction of left TVC (D).

ing. He was unable to move the tongue in any directions, only could protrude minimally (Fig. 1A). The otorhinolaryngology department received the urgent call, and we performed the flexible laryngoscopy. It revealed midline position of both vocal folds with minimal mucosal vibration (Fig. 1B). Other neurologic examination was unremarkable. We estimated as bilateral RLN and HN palsy. The neck computerized tomography (CT) scan showed totally obstructed glottic chink. The brain $\mathrm{CT}$ and MR images with angiography showed unremarkable. The viral titers of herpes, adenovirus and infectious mononucleosis were within normal limits. We diagnosed as bilateral Tapia's syndrome. Emergent tracheotomy was performed to secure airway and nasogastric tube was inserted. We started the oral prednisolone therapy $(1 \mathrm{mg} / \mathrm{kg} /$ d), vitamin $B_{6}$ and $B_{12}$. After two weeks, the movement of left true vocal cord was recovered. Three months later, the tongue motion was completely restored but right RLN palsy was persisted (Fig. 1C and D). Until the one year, he only complains of mild hoarseness and dysphagia.

\section{Discussion}

The peripheral causes of the Tapia's syndrome include metastatic hemangiosarcoma, vagal and hypoglossal schwannomas, neck surgery, radiation, fungal and viral infections, carotid artery dissection and idiopathic etc. ${ }^{2,6)}$ In most of Tapia's syndrome, the obvious etiology remains unclear. But we carefully assume two possible mechanisms through the previous reports and our case; the first is anesthetic points concerning the anatomy of both nerves and the second is surgical aspects.

Anatomically the hypoglossal and vagus nerves closely run around the lateral wall of the lower oropharynx and the upper hypopharynx. If If the compression by mal-positioned intubation tube is occurred at the crossing point of both nerves, especially simultaneously with hyperextension or lateral flexion of the neck, these conditions may provoke the neuroprax- ic injury of both nerves. ${ }^{1,4)}$

In surgical aspects, the incidence of vocal cord palsy in open heart surgery is known to be about $0.67-1.9 \%$. $^{7}$ The left RLN is more vulnerable to the injury, because of its long intra-thoracic pathway. ${ }^{8,9)}$ The possible etiologies of injury include retraction with excessive hyper-extension and lateral flexion of neck in median sternotomy, dissection of the superior part of the ITA, topical cardio-protective ice, electrocautery and hematoma etc. ${ }^{8,9)}$ Furthermore, the bilateral harvesting of ITA may increase the risk of both RLN injury like our case." $\mathrm{Be}$ cause both ITA run hooks around the subclavian artery, the right RLN is more vulnerable to the injury than left side. ${ }^{9)}$

Bilateral Tapia's syndrome is extremely rare disease entity. Until now, only three cases are reported in English literature. ${ }^{3-5)}$ Because the injury mechanism is almost neuropraxia, full recovery has been noted within couple of months. ${ }^{5)}$ In general, the recovery time of RLN is more rapid than $\mathrm{HN}^{5)}$ Unfortunately, the right RLN palsy was persistent in our case. It is presumed to receive a neuronal degeneration by direct trauma. The differential diagnosis of Tapia's syndrome include carotid artery dissection involving the ascending pharyngeal artery, basal skull fracture involving the jugular and hypoglossal foramina, nasopharyngeal fungal infection and neurofibromatosis etc. ${ }^{6}$

The syndrome usually occurs during general anesthesia, except only one case of local block into the interscalene brachial plexus. ${ }^{10)}$ It means that the mechanism of the disease is somewhat associated with the general anesthesia. During anesthesia, the preventive points are gentle anesthetic manipulation during in- and extubation, adequate cuff pressure, tube position and short anesthetic time. Special attention should be paid to preventive strategies.

To the best of our knowledge, this case is the first report about bilateral hypoglossal and recurrent laryngeal nerve injury together in association with putative direct injury mixed with orotracheal intubation. 


\section{REFERENCES}

1) Lykoudis EG, Seretis K. Tapia's syndrome: an unexpected but real complication of rhinoplasty: case report and literature review. Aesthetic Plast Surg 2012;36(3):557-9.

2) Boğa I, Aktas S. Treatment, classification, and review of Tapia syndrome. J Craniofac Surg 2010;21(1):278-80.

3) Cinar SO, Seven H, Cinar U, Turgut S. Isolated bilateral paralysis of the hypoglossal and recurrent laryngeal nerves (Bilateral Tapia's syndrome) after transoral intubation for general anesthesia. Acta Anaesthesiol Scand 2005;49(1):98-9.

4) Sotiriou K, Balanika M, Anagnostopoulou S, Gomatos C, Karakitsos D, Saranteas T. Postoperative airway obstruction due to Tapia's syndrome after coronary bypass grafting surgery. Eur J Anaesthesiol 2007;24(4):378-9.

5) Turan I, Yildirim ZK, Tan H. Bilateral Tapia syndrome secondary to oropharyngeal intubation. J Neurosurg Anesthesiol 2012;24(1):78.
6) Kashyap SA, Patterson AR, Loukota RA, Kelly G. Tapia's syndrome after repair of a fractured mandible. Br J Oral Maxillofac Surg 2010; 48(1):53-4.

7) Dimarakis I, Protopapas AD. Vocal cord palsy as a complication of adult cardiac surgery: surgical correlations and analysis. Eur J Cardiothorac Surg 2004;26(4):773-5.

8) Nalladaru Z, Wessels A, DuPreez L. Tapia's syndrome--a rare complication following cardiac surgery. Interact Cardiovasc Thorac Surg 2012;14(1):131-2.

9) Protopapas AD. Bilateral harvesting of internal thoracic artery for coronary bypass: augmenting the risk for postoperative airway obstruction? Eur J Cardiothorac Surg 2003;23(1):137-8; author reply 138 .

10) Johnson TM, Moore HJ. Cranial nerve X and XII paralysis (Tapia's syndrome) after an interscalene brachial plexus block for a left shoulder Mumford procedure. Anesthesiology 1999;90(1):311-2. 